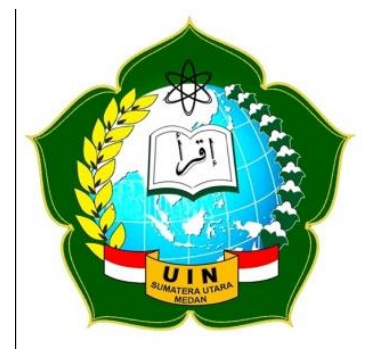

VISION JOURNAL

http://jurnaltarbiyah.uinsu.ac.id/vision

\title{
AN ERROR ANALYSIS OF RECOUNT TEXT TRANSLATION BY EFL PRE- SERVICE TEACHERS
}

\author{
Juniharma Dewi Dalimunthe \\ Department of English Education, UINSU \\ Email: juniharma30@gmail.com
}

\begin{tabular}{|c|c|}
\hline Keywords & Abstract \\
\hline $\begin{array}{l}\text { Keywords: Error Analysis, } \\
\text { Recount Text, Translation, EFL } \\
\text { Pre-service Teachers. }\end{array}$ & $\begin{array}{l}\text { This study aims to identify the errors and to describe the types } \\
\text { of errors made by EFL Pre-service Teachers when translating } \\
\text { recount texts from Indonesian to English. This research } \\
\text { employed a qualitative descriptive method. The subject of this } \\
\text { research is the 4th-semester student of the English Education } \\
\text { Department, State Islamic University of North Sumatera. This } \\
\text { research uses random sampling. The researcher only took data } \\
\text { from } 2 \text { representatives from each class. The data were taken } \\
\text { from translation tests and documentation. Based on the data, it } \\
\text { is found that there are } 38 \text { and eleven types of errors made by } \\
\text { the EFL Pre-service Teacher. The findings show that EFL Pre- } \\
\text { service teachers make errors in terms of article error, plural } \\
\text { noun error, punctuation error, phrase error, verb error, } \\
\text { preposition error, misordering error, pronoun error, noun error, } \\
\text { infinitive error, and spelling error. There is some process of the } \\
\text { error occurred, namely: hesitates in using an appropriate article, } \\
\text { doesn't pay much attention to grammar in the target language, } \\
\text { misplaced punctuation, doesn't understand the rules of using } \\
\text { the correct preposition and don't understand the use of pronouns } \\
\text { in sentences. The causes of errors on EFL Pre-service Teachers } \\
\text { in translating Recount Text are lack of motivation and } \\
\text { Interlingual transfer/intralingual transfer. }\end{array}$ \\
\hline
\end{tabular}

Faculty of Tarbiyah and Teacher Training, 1st Floor

Jalan Willem Iskandar Psr V Medan, 20731

Telp. 061- 6622925 - Fax. 061 - 6615685 


\section{INTRODUCTION}

Translation course is a compulsory subject that must be studied and the skill must be mastered by English Education Department Students/EFL Pre-service Teachers. Based on the curriculum and syllabus of the English Education Department at Universitas Islam Negeri Sumatera Utara (the State Islamic University of North Sumatera) Medan, the translation course aims to provide translation competence to students. Then, they have insight and experience in the world of translation, especially in translating English into Indonesian or Indonesian into English. This translation course provides practical experience for students so that they can use computers as a tool for translation and increase student knowledge about translating.

Translation is the process of replacing textual materials in one language with similar textual materials in another. Words, phrases, sentences, language form, and grammatical structure are all examples of textual materials. Translators should be able to identify the most appropriate words, phrases, sentences, or grammatical constructs to replace the source text for target readers to understand the target text (Catford, 1978). Thus, errors and mistakes made in translating a text will cause the target audience unable to comprehend the target text. So, the negative effect is when English Education Students or Prospective English Teachers cannot translate properly and correctly translated English into Indonesian or Indonesian into English, the translation results will sound unnatural and the reader will have difficulty understanding the translating text.

In translating the text, the English Education Department Students/ EFL Pre-service Teachers often make mistakes. The following are mistakes that are often made by students based on previous research: Source text "atas nama", incorrect translation "on name", it should be "on behalf of". Source text "kedudukan hukum", incorrect translation "the position of law", it should be "legal standing". Source text "payung hukum", incorrect sentence "legal umbrella", it should be "legal protection". The last, Source text "Komunikasi merupakan sebuah proses dalam mana seseorang atau beberapa orang, kelompok, organisasi, dan masyarakat menciptakan, dan menggunakan informasi agar terhubung dengan lingkungan dan orang lain", incorrect sentence "Communication is a process in which someone or some people, groups, organizations and communities create, and use information to connect with the environment and others", it should be "Communication is a process when someone or some people, groups, organizations and communities create, and use information to connect with the environment and others" (Kembaren, 2019).

Identifying errors in translating text is important for lecturers to be able to compile curriculum and teaching materials that are designed to overcome the problems in question and 
EFL Pre-service Teachers need to be able to correct and anticipate the occurrence of the same mistakes, so this research was carried out. As stated by previous research, that some of the advantages for English Education Department Students/EFL Pre-service Teachers who can translate are the ability to analyze translation techniques, translation quality, and participating ideology, conducting translation research for publications, and participating in national and international conferenced of translation field as presenters. Students will be able to translate different kinds of text, looking for clients for their translation agency, learn about entrepreneurship by guiding the students to run a translation agency service that can give them basic experience as translators (Kembaren, 2019).

Therefore, the present study was conducted 1) to explain the errors are made by EFL Preservice Teachers when translating Recount text from Indonesian into English, 2) to describe the types of errors are made by EFL Pre-service Teachers when translating Recount text from Indonesian to English. The significance of this study is as an information for teacher/lecturer, EFL Pre-service Teachers, and other researchers.

\section{LITERATURE REVIEW}

\section{Error Analysis}

Error analysis is a way to assess the effect of ineffective language, nature, causes, and consequences (James, 2013). Besides, Error analysis is a tool for evaluating errors in language learning. The errors can be studied and tracked to determine the causes (Sitorus \& Sipayung, 2018).

Error indicate gaps in a learner's knowledge; they arise when the learner is unsure of what is right. On the other hand, Error represent rare lapses in performance caused by the learner's inability to put what she/he has learned into practice (Krisnawati, 2013). Through rechecking the mistake with the students, they would be able to understand and correct the error that they have made. It is shown that the mistake made by the students was an "error in results" or a "mistake". However, if the students are unable to identify and correct their errors, the mistake is classified as an "error incompetence" or "error".

By conducting an error analysis, it is hoped that the error of the students can be eliminated, so that the ability of the students in English is significantly improved. There are four steps to performing error analysis (Gass \& Selinker, 1994) namely: Identifying the errors, classifying the errors, quantifying the errors, analyzing source of error. 
Errors made by the translator, which are not simply due to chance linguistic error are caused by a translator's lack of familiarity with the target language (source language). Translation errors are caused by a variety of factors, including a lack of understanding or the misuse of phrases. Misunderstanding and misuse of words are two common causes of mistranslation (Wongranu, 2017). Factors such as the lack of capacities of intelligent devices and translators' realistic resources may also contribute to a translation error.

\section{Translation}

The translation is the method of translating the meaning of a first language text into a second language text. It should be able to adequately translate the source language's vocabulary, grammatical structure, communication condition, and cultural meaning into the target language. The translation is a method of replacing or converting messages, feelings, ideas, meanings, or information from the source language to the target language. The key point of the translation is that the context of the original text's message cannot be changed by the translator.

Translation necessitates a significant amount of cultural awareness (Olk, 2003). Translators must have a cultural understanding of English culture in the translation of genuine materials like English magazines or newspapers. The aim of teaching translation is that students are expected to be able to translate text in the source language into a target language that has equal meaning and to replace messages and written statements in one language with the same messages and questions in another language. When applied in daily class activities, translation can help students develop and improve skills, namely speaking, grammar, vocabulary, and writing.

The translation of text from Indonesian into English includes two key problems or vice versa: a. The differences between Indonesian and international, b. English as part of culture is not mastered through translations. In addition, Hoed adds that the translation of texts has two practical problems: a. Translators do not understand the importance of the sentences, phrases, or paragraphs, and cannot understand the source text message, b. Despite their comprehension of the source material, translators are difficult to interpret sentences, phrases, or paragraphs (Hoed, 2006).

Translation strategies are important because they influence how translators interpret recount texts. There are also translation approaches, translation processes, and translation techniques in addition to tactics in translation. The translation technique is a translator's tactic 
of translating a word or a group of words, or even complete sentences, when the sentence can be broken down into smaller translation units (Kardimin, 2013).

According to Suryawinata \& Hariyanto, The translation method comprises three stages, as follows:

a. Analysis of Source Language Text

An analysis of the source language text begins with each translation operation, as the translator often first meets the source language. The translator must read the message of the source language, then the translator understands the content of the text. Source language analysis encompasses several topics, such as sentences, clauses, phrases, and terms. The other aim is to help the translator transform the complicated sentence into a simple sentence.

b. The Transference of Message

The content message can be caught until the translator has grasped the context and structure of the source language text. The next step is to translate the source language's content, context, and message into the target language. The translator must determine the meaning of the source language words in this process.

c. Restructuration

Restructuration is the process of translating a source language message into a proper stylistic form in the target language, so the translator must pay attention to the language style to correct the language style that is suitable for the text type, and they must also consider to whom the translation is made in this process (Suryawinata \& Hariyanto, 2003).

\section{Recount Text}

Recount text is written to provide information about past events. The recount text is divided into three groups. They are personal text recounts, which include details or a story about the author's personal experience. For example, the diary of a person, or a biography, etc. Then, the actual recount text that contains a report about the actual events that had happened. For example, a police report, a science experiments report, a record historical events report, and a cultural report. The last, imaginative recount, contains a story of imagination, recounting the results of the imagination of the author. For example, fiction in short stories, novels, etc (Derewianka, 1990). 


\section{METHOD}

The participants of the study were eight EFL Pre-service teachers at the English Education Department, State Islamic University of North Sumatera in the $4^{\text {th }}$ semester. The researcher only took data from 2 representatives from each class. In conducting this research, the method used in this study is a qualitative descriptive method because this study aims to describe the translation errors made by EFL Pre-service Teachers.

To collect this research data, researchers collected data with the following techniques: 1). Translation test, the researcher instructed the students to translate Recount text from Indonesian into English. After the test was complete, the researcher collected answers via WhatsApp because the students are currently still learning online. It was made easier for the researcher to identify translation errors made by the students in translating Indonesian texts into English. 2). Documentation, the researcher has used documentation as a technique of collecting data. The researcher took a screenshot of the student's recount text as evidence of the data to be valid.

This research was analyzed by adopting Ellis's approach of Error Analysis, it was divided into four categories, such as: identifying the errors, describing the errors, explaining or interpreting the errors, and evaluating the errors (Ellis, 2008). The errors were categorized into four namely: article error, punctuation error, preposition error, and pronoun error. Then, the data analysis was carried out by the researcher herself and reviewed by a colleague and the translation lecturer.

\section{FINDING AND DISCUSSION}

\section{Total Errors Made by the EFL Pre-Service Teachers}

After analyzing the data, the findings reveal that in general there are 38 and 11 types of errors made by the EFL pre-service teachers in translating texts from Indonesian into English:

Table 1. Types and Amounts of Students' Error

\begin{tabular}{llll}
\hline No. & \multicolumn{1}{c}{ Types of Error } & & Amount \\
\hline 1. & Article Error & 4 & \\
2. & Plural Noun Error & 1 & \\
3. & Punctuation Error & 15 \\
4. & Phrase Error & 3 \\
5. & Verb Error & 2 \\
6. & Preposition Error & 5 \\
7. & Misordering Error & 1 \\
8. & Pronoun Error & 3 \\
9. & Noun Error & 1 \\
\hline
\end{tabular}




\begin{tabular}{lll}
\hline 10. & Infinitive Error & 1 \\
11. & Spelling Error & 2
\end{tabular}

\section{Result: 38}

Based on table 1.1 above, there are 38 and eleven types of errors made by the EFL pre-service teachers, they are elaborated below:

a. Article Error

e.g :

1) We also take a breakfast together.

2) There were many plants belong to grandmother there.

3) I went to the Sidadi village to visit grandma.

4) The next day, grandmother took us to the garden.

b. Punctuation

e.g :

1) In the garden there are trees of rambutan, durian, mango, grapes, and watermelon. [7 EFL pre-service teachers have made the same mistake].

2) usually the harvest that is obtained is sold directly at the Pasar Pekan. [4 EFL pre-service teachers have made the same mistake].

3) Grandma really likes gardening, usually the harvest that is obtained is sold directly at the Pasar Pekan. [3 EFL pre-service teachers have made the same mistake].

4) After that the uncle and aunt to pick up as at the terminal.

c. Verb Error

e.g :

1) It was our first time to go there.

2) We depart from Medan to the Sidadi village by use the Bus at 19:00 PM.

d. Preposition Error

e.g :

1) We arrived at sidadi village's bus station about $7 \mathrm{am}$.

2) For the last December, I went to the Sidadi Village to visit my grandmother.

3) I want to visit at Sidadi Village again with my family on another occasion.

4) pick up as at the terminal.

5) I want to visit the Sidadi village again with my family on another time. 
e. Pronoun Error

e.g :

1) the water was very clear there and many villagers who used the water for washing clothes, washing dishes, and bathing.

2) We went there by motorcycle because the distance between grandmother's house and the garden was quite far.

3) My siblings and me toured the village.

f. Spelling Error

e.g :

1) We also went to the river, was there the water is crystal clear.

2) we finally comeback to Medan.

g. Plural Noun Error

e.g :

1) We also went to the river, where the water was very clear and many resident used the water to wash clothes, wash dishes and bathe.

h. Phrase Error

e.g :

1) Grandma really likes gardening. [3 EFL pre-service teachers have made the same mistake].

i. Misordering Error

e.g :

1) We saw that there were many trees and plants thriving.

j. Noun Error

e.g :

1) In the garden, there were rambutan, durian, mango, grape, and watermelon's tree.

k. Infinitive Error

e.g :

1) After that the uncle and aunt to pick up as at the terminal.

2. Types of Error Made based on The Suggested Framework 
Based on the four categories mentioned in the research method, the results of data analysis reveals that the four categories namely: article error, punctuation error, preposition error, and pronoun error are found in data, the elaboration of the findings is presented below:

\section{a. Article Error}

Article error is a grammatical error that occurs when converting Indonesian to English and involves inaccuracy in determining the article of a sentence. This is shown in the result of data analysis that one of the EFL Pre-service Teachers translated "Kami juga serapan bersama" into the target language [We also take a breakfast together] (St.1-Tr-Er-Ae). In this sentence, the indefinite article, a, may be redundant when used with the uncountable noun "breakfast" this sentence. So, the correct sentence is [We also take breakfast together].

This occurs when the EFL Pre-service teacher hesitates in using an appropriate article. In the sentence above the article "a" is not quite right if it is juxtaposed with the word "breakfast". Therefore, it would be better if the article "a" was omitted.

This happened because the EFL Pre-service teacher had doubts about the article "a". In Indonesian, there is no provision that in a sentence there must be an article. This makes EFL pre-service teachers find it difficult to adjust when translating Indonesian sentences into English. The EFL pre-service teacher is that the article "a" remains when juxtaposed with the word "breakfast".

\section{b. Punctuation Error}

A Punctuation error is an error in writing caused by misplaced punctuation. This is shown in the result of data analysis that one of the EFL Pre-service Teachers translated "Di kebun ada pohon rambutan, durian, mangga, anggur, dan semangka" into the target language [In the garden there are trees of rambutan, durian, mango, grapes, and watermelon] (St.1-St.3-St.4-St.5-St.6St.7-St.8-Tr-Er-Pue). It appears that the EFL Pre-service Teachers missing a comma after the introductory phrase in the garden. Consider adding a comma. So, the correct sentence should be [In the garden, there are trees of rambutan, durian, mango, grapes, and watermelon].

This is because the EFL Pre-service Teacher may have forgotten to put a comma after the word "in the garden". The function of the comma is to tell the reader when to pause. Commas also separate phrases, ideas, and items in a list. Commas help avoid. So that's why it's important to use commas after "in the garden,".

To give a better understanding of this, the EFL Pre-service Teacher should practice writing more often. EFL Pre-service Teachers must also understand the rules of writing such as placing commas, periods, exclamation points, and others. Because if a sentence should have 
a comma but we forget to make a comma, the sentence will have a different meaning. Therefore, placing a comma in a sentence is very important.

\section{c. Preposition Error}

Preposition error is a type of translation error that occurs when the preposition of place in a sentence is incompatible. This is shown in the result of data analysis that one of the EFL Pre-service Teacher translated "Desember lalu, saya pergi ke Desa Sidadi untuk mengunjungi nenek" into the target language [For the last December, I went to the Sidadi Village to visit my grandmother] (St.3-Tr-Er-Pre). It seems that preposition use may be incorrect here. Consider removing "for". It should be [The last December, I went to the Sidadi Village to visit my grandmother].

In the sentence above, the EFL Pre-service Teacher translates the word "last December" into the target language into "For the last December,". In grammar, the word "for" when combined with the word "the last December" becomes an error sentence. A good translation should be "The last December,...".

The error occurred because the EFL Pre-service Teacher translated by adding "for" after the word "the last December". If the EFL Pre-service Teacher only translates the word "the last December" it is correct. This may have happened unconsciously when the EFL Preservice Teacher translated "for the last December", but it was an almost fatal error. Therefore, it would be better if the EFL Pre-service Teacher had to be more careful in translating the text.

\section{d. Pronoun Error}

Pronouns are used instead of nouns (things or people) in English, so your writing does not appear wordy or repetitive. The pronoun must accept the substitution of the noun whether it is an object, a subject, or possessive. This is shown in the result of data analysis that one of s EFL Pre-service Teacher translated "disana airnya sangat jernih dan banyak penduduk desa yang memanfaatkan air tersebut untuk mencuci baju, mencuci piring, dan mandi" into target language [The water was very clear there and many villagers whe used the water for washing clothes, washing dishes, and bathing] (St.2-Tr-Er-Pe). It seems that is a pronoun problem here. So, the correct sentence [The water was very clear there and many villagers used the water for washing clothes, washing dishes, and bathing].

In this case, the EFL Pre-service Teacher translating from source language to target language experienced an error in using pronouns. The error occurred when the EFL Pre-service Teacher translated “...many villagers used...." becomes “...many villagers who used...”. If 
you use the word "many villagers" this sentence is complete. The "who" function here is only to explain many villagers. However, it would be better if the word "who" was removed.

In this case, it would be even better if the EFL Pre-service Teacher paid more attention to the use of "who". In the sentence above there is already a subject and if you add the word "who" will make this sentence have 2 subjects. Therefore, EFL Pre-service Teacher should better understand the "who" function in a sentence. So that the sentence does not become ambiguous.

Based on the data above, there were 11 types of errors found, namely article error, plural noun error, punctuation error, phrase error, verb error, preposition error, misordering error, pronoun error, noun error, infinitive error, and spelling error. Based on the explanation above, it can be concluded that several types of errors have been described in previous theories and research. However, there were some errors found in this study. This is what distinguishes this study from previous research. In her research, Dina Merris found that there were two student errors in translating recount text, namely lexical errors and grammatical errors. The grammatical error section is divided into three, namely preposition errors, errors in the use of tenses, and incomplete sentences (Sari, 2019). Selvia \& Susi also found four student errors in writing recount text, namely, the error of omission, the error of addition, error of selection, and error of misordering (Asni \& Susanti, 2018).

Therefore, errors that often occur when students/translators translate texts are due to the differences between Indonesian and English. In addition, students/translators still have a poor vocabulary. Then, they do not understand specific terms, idioms, and word choices. Thus, Translators should focus on the message rather than the words, and they should be able to select the appropriate words to accurately communicate the source text's content in the target text (Kembaren, 2019).

\section{CONCLUSION}

There are 11 errors made by EFL Pre-service Teachers in translating Indonesian into English. They are article error, plural noun error, punctuation error, phrase error, verb error, preposition error, misordering error, pronoun error, noun error, infinitive error, and spelling error. There is some process of the error occurred, they are: hesitates in using an appropriate article, doesn't pay much attention to grammar in the target language, misplaced punctuation, doesn't understand the rules of using the correct preposition and don't understand the use of pronouns in sentences. 
The causes of errors on EFL Pre-service Teachers in translating Recount Text are Interlingual transfer and intralingual transfer; this is because the EFL Pre-service Teacher does not understand the methods of translating such as: Analysis of source-language text, transference of message, and restructuring. The EFL Pre-service Teacher translates word by word and does not pay attention to the structure of the target language. Lack of motivation; EFL Pre-service Teachers feel a lack of motivation to learn "Translation" even though it is very important. They are also still lacking in the use of grammar.

\section{REFERENCE}

Asni, S. L., Susanti, S., \& Sulistiyo, U. (2018). An analysis of grammatical errors in Writing Recount text at the eighth grade of SMP negeri 20 Kota jambi. International Journal of Language Teaching and Education, 2(2), 131-144.

Catford, J. C. (1978). A linguistic theory of translation: An essay in applied linguistics. Oxford University Press. .

Derewianka, B. (1990). Exploring how texts work. Primary English Teaching Association.

Ellis, R. (2008). The study of second language acquisition. Oxford University Press.

Gass, S. M., \& Selinker, L. (1994). Second language acquisition : An introductory course.

Hoed, B. H. (2006). Penerjemahan Dan kebudayaan. Pustaka Jaya.

James, C. (2013). Errors in language learning and use: Exploring error analysis. Google Books.

Kardimin. (2013). Pintar Menerjemah Wawasan Teoritik dan Praktek Pustaka Pelajar.

Kembaren, F. R. W. (2019). Translation studies from theory and practice. Repository UIN Sumatera Utara.

Krisnawati, E. (2013). Error or mistake? Incorrectness in students' answers in a subject-matter examination. International Journal of Language Learning and Applied Linguistics World.

Olk, H. (2003). Cultural knowledge in translation. ELT Journal, 57(2), 167-174.

Sari, D. M. (2019). An error analysis on student's translation text. Eralingua: Jurnal Pendidikan Bahasa Asing Dan Sastra, 3(2).

Sitorus, G. S., \& Sipayung, K. (2018). An error analysis of using phrases in Writing Recount text at tenth grade IN SMA parulian 2 medan. Celt: A Journal of Culture, English Language Teaching \& Literature, 18(1), 74. 
Journal VISION, Vol. XVII. No.2 (July-Desember 2021). Page 43-55

Suryawinata, Z., \& Hariyanto , S. (2003). Translation: Bahasan teori \& penuntun praktis menerjemahkan.

Wongranu, P. (2017). Errors in translation made by English MAJOR Students: A study on types and causes. Kasetsart Journal of Social Sciences, 38(2), 117-122. 